\title{
Semua Berawal dari IT: Terobosan Banyuwangi dalam Menata Ulang Tatakelola Pemerintahan
}

\section{Teguh Yuwono', Laila Kholid Alfirdaus ${ }^{2}$, D. Ghulam Manar ${ }^{3}$}

1,2,3 Prodi Ilmu Pemerintahan, Universitas Diponegoro

\begin{abstract}
Abstrak:
Tidak ada yang meragukan bahwa IT (Information and Technology) adalah kunci dalam menyambut perubahan 4.0 yang dipandang telah mendisrupsi banyak hal. Namun demikian, tidak banyak unit-unit pemerintahan yang secara cepat beradaptasi dengan situasi baru. Di tengah respon yang cukup kalang-kabut oleh pemerintah, baik di tingkat pusat maupun daerah, Banyuwangi relatif mampu melakukan penyesuaian diri dengan perubahan-perubahan baru yang berlandaskan Internet-of-Thing (IoT). Tentu saja, Banyuwangi tidak sedang menuju untuk menjadi seperti Silicon Valley, Amerika Serikat, yang telah lama dikenal sebagai episentrum bisnis-bisnis IT global. Banyuwangi masih sebatas gesit dalam memanfaatkan keterbukaan akses dan informasi untuk masuk ke dalam alur bisnis berbasis IT yang semakin ekspansif. Dampak dari kecepatan penyesuaian diri tersebut telah berhasil mengubah banyak hal menjadi lebih baik di masyarakat, baik secara ekonomi, pelayanan publik, maupun pendidikan. Hasil penelitian penulis selama tahun 2019 menunjukkan bahwa inovasi IT oleh Pemerintah Kabupaten Banyuwangi menjadi jantung bagi perubahan banyak aspek kehidupan di sana. Inovasi ini kemudian merangsang lahirnya inovasi baru di banyak hal lainnya
\end{abstract}

Keywords:

informasi dan teknologi; inovasi; tata kelola pemerintahan

\section{Pendahuluan}

rtikel ini membahas inovasi IT (Information and Technology) yang dilakukan
pemerintah Banyuwangi di bawah kepemimpinan Bupati Abdullah
Azwar Anas (2010-2015 dan 2015-2020) yang menjadi jantung penataulangan tata kelola pemerintahan di daerah tersebut. Menariknya, kami berargumen, inovasi IT tidak hanya berhenti sebagai instrumen yang memperbaiki kinerja birokrasi dan pelayanan publik. Lebih dari itu, inovasi IT menjadi pemicu bagi inovasi-inovasi di bidang lain di Kabupaten Banyuwangi.

Sudah ada beberapa tulisan yang mendiskusikan terobosan pemerintah Banyuwangi di bawah kepemimpinan Azwar Anas. Sebagai contoh adalah diskusi 
tentang Smart Kampung yang dilihat sebagai inovasi pelayanan publik di level lokal Aji \& Dharmawan; Wahono (2018 \& 2016), inovasi kesehatan berbasis IT (Asmara \& Rahayu 2019 \& 2020), pelayanan aduan berbasis IT (Widodo, 2019). Tulisan-tulisan ini memberikan informasi tentang berbagai keberhasilan maupun hambatan yang dihadapi Pemerintah Banyuwangi mendorong terobosan-terobosan pelayanan berbasis IT. Deretan penelitian terdahulu tersebut memberi informasi penting terkait ranah-ranah inovasi yang diinisiasi oleh Pemerintah Kabupaten Banyuwangi.

Namun demikian, belum banyak kajian yang mengaitkan berbagai terobosan yang dilakukan oleh pemerintah Kabupaten Banyuwangi dalam satu benang merah tertentu, sehingga akan memudahkan publik untuk membayangkan bagaimana terobosan itu dilakukan dan memungkinkan untuk diaplikasikan di tempat lain. Tulisan ini mencoba mengisi kekosongan tersebut dengan memfokuskan diskusi pada kajian inovasi IT dalam pemerintahan serta implikasinya terhadap inovasi-inovasi lanjutan yang saling bersambungan.

Secara khusus artikel ini dimaksudkan untuk mengisi celah diskusi akademik tentang inovasi kebijakan yang tidak banyak menaruh perhatian pada peletakan IT sebagai jantung terobosan pemerintahan. Rata-rata, diskusi inovasi kebijakan meletakkan IT sebatas sebagai instrumen yang fungsinya sebagai penopang/pendukung. Dari kasus Banyuwangi, kita bisa melihat bahwa keberhasilan reformasi pemerintahan bukan diawali dari kocok ulang pejabat (mutasi), atau pengetatan standar operasional, tetapi dari inovasi IT, dimana IT ditempatkan sebagai contentatau isi dari inovasi itu sendiri, untuk kemudian menjadi pemantik bagi inovasi-inovasi di bidang lain.

Artikel ini didasarkan pada penelitian lapangan yang dilakukan selama tahun 2019 dengan lokus pada IT dan terobosan-terobosan penataulangan tatakelola pemerintahan di daerah. Sebanyak 25 informan berhasil diwawancara. Informaninforman tersebut mencakup Bupati Banyuwangi, Abdullah Azwar Anas, Kepala Dinas Komunikasi, Informatika dan Persandian, Sekretaris Dinas Komunikasi dan Informasi, Kepala Bagian-Kepala Bagian di Sekretaris Daerah, Dinas Komunikasi, Informatika dan Persandian, Dinas Pariwisata, Dinas Pertanian dan Pangan, Kepala Desa, pelaku usaha menengah dan kecil, Kantor Pajak, Lembaga Swadaya Masyarakat (LSM), dan masyarakat biasa.

\section{IT dan Inovasi Tatakelola Pemerintahan: Tinjauan Pustaka}

Sebagaimana kita ketahui bersama, inovasi berbasis IT terdengar sangat common sense dan sudah dimaklumi khalayak di tengah perkembangan teknologi informasi dan Internet-of-Thing akan memudahkan beragam pekerjaan (Marburger, 2011: 213). Pemerintah daerah sudah menggunakan computer alih-alih mesin ketik. Aduan pelayanan masyarakat sudah banyak yang berbasis media sosial daripada kotak saran manual. Dialog dengan kepala daerah tidak sedikit yang dilakukan lewat online 
disamping dengan berbagai kegiatan anjangsana. Namun demikian, dalam praktiknya tidak sedikit pemerintah daerah yang masih kesulitan untuk memperluas dampak inovasi IT terhadap perubahan-perubahan yang di sektor lain. Padahal, sebagaimana Cheng \& Wang (2019), dampak multiplier inovasi teknologi menjadi kunci untuk mempercepat pertumbuhan ekonomi.

Tidak dipungkiri, hambatan transformasi budaya kerja dari manual ke digital tidak ringan. Tidak sedikit pemerintah daerah yang mengeluh betapa transformasi IT di lingkungan birokrasi adalah hal yang alot untuk diwujudkan. Tantangan budaya birokrasi, kualitas sumber daya manusia (SDM) Foreman-Peck (2013: 55), Hall \& Van Reenen (2000) \& Jones \& Williams (1998), serta aspek politik menjadi salah satu penjelasan beratnya mengubah birokrasi menjadi lebih responsif terhadap perkembangan teknologi guna memperbaiki pelayanan publik (Jacobs \& Weaver, 2015: 444). Tidak mengherankan jika pelayanan berbasis online di Indonesia terkesan baru saja dimulai, walau jaringan internet beserta wacana E-Government telah digulirkan sejak dua atau tiga dasawarsa yang lalu.

Terkait hal ini, sebagaimana sudah jamak diketahui, hal yang paling sulit bagi sebuah pemerintahan adalah melakukan perubahan. Birokrasi telah bekerja selama bertahun-tahun dengan standar operasional yang sama, tentu saja sudah hafal semua rangkaian regulasi dan prosedur, serta nyaman dengan budaya kerja yang terbangun. Hasilnya, unit-unit pemerintahan dinilai paling lama merespon perubahan, kalah cepat dengan sektor swasta. Ketika tuntuan perubahan mulai menguat, dikarenakan perubahan yang sangat cepat di masyarakat, tidak sedikit lembaga-lembaga pemerintahan yang mengalami kesulitan dan membutuhkan waktu yang lama untuk melakukan penyesuaian. Lebih-lebih, tidak jarang, birokrasi sendiri menjadi penghambat inovasi. Sulitnya unit-unit pemerintahan menyesuaikan diri dengan perkembangan teknologi informasi menjadi gambaran yang umum bagi negara berkembang seperti Indonesia.

Tidak sama dengan daerah lain, Banyuwangi memiliki cerita tentang reformasi tatakelola pemerintahan yang diawali dari inovasi IT. Memang terdengar sudah jamak. Namun demikian, yang menarik adalah menelisik bagaimana penataulangan tatakelola pemerintahan ini diikuti langkah-langkah lanjutan secara lebih detil. IT ditempatkan sebagai payung bagi inovasi-inovasi yang lain. Dari penelusuran penulis selama melakukan penelitian lapangan pada tahun 2019, titik mula inovasi ini berawal dari perekrutan PNS di daerah tersebut. Bupati Azwar Anas meminta secara khusus kepada panitia seleksi untuk membuka formasi lulusan IT, ditambah dengan formasi lulusan akuntansi guna mendukung tatakelola pemerintahan yang transparan. Memiliki SDM IT, bagi Bupati Anas adalah awal mula yang penting guna memungkinkan pemerintah melakukan transformasi pelayanan publik yang seiring sejalan dengan perkembangan di masyarakat yang sudah sangat terikat dengan Internet.

Dari perekrutan PNS tersebut, kebijakan beranjak pada perubahan tatakelola $E$ Government. Jika daerah lain lebih sering melakukan sub-kontrak kepada pihak ketiga guna 
menyediakan layanan berbasis Internet, Banyuwangi mengelola sendiri sistem IT-nya. Hal ini menguntungkan pemerintah karena sistem IT lebih berkelanjutan dan tidak tergantung pada kontrak. Inovasi terus berlanjut, merambah pada program melek internet di desa-desa, yang dikenal dengan nama "Smart Kampung". Dengan "Smart Kampung", masyarakat di pedesaan dapat memiliki akses internet yang disediakan di tempat-tempat publik guna memperoleh pelayanan kependudukan yang lebih praktis, sekaligus mengabarkan potensi daerah masing-masing, khususnya pariwisata, pertanian dan perikanan kepada khalayak umum, termasuk yang terhubung secara virtual. Selain itu, pelaporan anggaran di level pemerintahan desa juga mudah diakses oleh masyarakat karena dibuka secara transparan melalui aplikasi.

Tentu saja, tidak sedikit kritik yang diajukan, seperti keberhasilan kebijakan ini menyatu kedalam sistem birokrasi yang biasanya konvensional di masa mendatang. Selain itu, kebijakan ini juga menimbulkan resistensi bagi para birokrat yang sudah merasa mapan dengan apa yang selama ini dilakukan. Namun demikian, seiring berjalannya waktu, dan manfaat yang lebih luas dirasakan masyarakat, kebijakan ini mendapatkan dukungan politik yang memadai.

Artikel ini melihat penting sekali memperjelas pendekatan yang dipilih oleh entitas pemerintahan di negara berkembang dalam mengadopsi IT didalam tatakelola pemerintahannya. Adopsi bukan sekedar adopsi. Adopsi menjelaskan kepada kita bagaimana pemerintah meletakkan secara tepat posisi strategis IT dalam penataulangan tatakelola pemerintahan, alih-alih melihatnya sebagai beban. Di banyak tempat, pengenalan IT di lembaga pemerintahan lebih banyak dianggap sebagai beban kerja tambahan dibandingkan sebagai sarana yang memudahkan. Alasan sumber daya manusia yang terbatas Choi \& Chandler (2020), sumber pendanaan yang tidak mencukupi serta sulitnya mengubah budaya kerja birokrasi dari manual ke digital menjadi hal yang jamak ditemui (Asatryan, Heinemann, \& Pitlik, 2017; Buso, Marty, \& Tran, 2017; Effah \& Nuhu, 2017).

Sebagaimana studi kasus di Banyuwangi, IT ditempatkan sebagai permulaan (milestone) sekaligus jantung bagi tata ulang pemerintahan kabupaten. Walau tidak mudah, reformasi yang dipaksakan ini lama-lama membuat para birokrat terbiasa, dan kini, dapat dikatakan rata-rata para birokrat di Banyuwangi ahli dalam melakukan pelayanan publik berbasis IT. Menariknya, berdasarkan temuan penelitian di lapangan, inovasi IT ini kemudian menular pada inovasi-inovasi lainnya. Pertama, tentu saja adalah inovasi pelayanan publik, tetapi yang paling terasa adalah inovasi di sektor pariwisata. Pasalnya, dari inovasi di sektor pariwisata ini kemudian menjalar pada inovasi-inovasi lainnya, mencakup inovasi tatakelola UMKM, investasi, dan transportasi.

Pengalaman Banyuwangi mengingatkan kita pada argumen Licht \& Moch, DLicht, G. \& Moch (1999: 365) yang menyebut inovasi IT sebagai investasi yang penting dalam pemberian pelayanan. Sebagaimana penjelasan Licht \& Moch, DLicht, G. \& Moch, (1999: 365), inovasi IT dapat mendorong produktivitas, dikarenakan peralatan IT yang canggih sangat mudah dikombinasikan dengan peralatan kinerja yang modern, 
khususnya yang berbasis komputer. Memperkuat Licht, G. \& Moch (1999), menjelaskan inovasi kebijakan, termasuk dalam kaitannya dengan inovasi IT, dapat mengubah budaya kerja birokrasi yang efektif selama birokrasi tersebut hidup dan tumbuh di lingkungan yang lebih simpel dan terbuka terhadap perubahan (Edmiston, 2003; Kakabadse, Kakabadse, \& Kouzmin, 2003; Welch \& Feeney, 2014: 514). Banyuwangi menjadi menarik karena birokrasi di Indonesia umumnya dikenal sebagai entitas yang komplek dan resisten terhadap perubahan. Tentu bukan berarti birokrasi di Banyuwangi berbeda dibandingkan dengan birokrasi lain di Indonesia pada umumnya. Tetapi, cara melihat dan menempatkan IT dalam reformasi tata kelola pemerintahan inilah yang menjelaskan mengapa reformasi birokrasi dapat menggelinding ke ranah-ranah yang lain.

Argumen yang dibangun di artikel ini sekaligus mengkritisi argumen West (2004) yang cenderung melihat kegagalan reformasi birokrasi berbasis IT lebih sebagai akibat dari terlalu kuatnya fokus pemerintah pada pada pengenalan teknologi dibandingkan pada perubahan budaya organisasi. Argumen West jelas mengimplikasikan bahwa IT hanya dilihat sebagai instrumen yang mungkin tidak akan banyak berarti dalam mendorong perubahan tatakelola pemerintahan. Bagi West (2004), perubahan budaya organisasi jauh lebih substantif dibandingkan inovasi IT. Artikel ini melihat apa yang dijelaskan West tidak sepenuhnya menjelaskan apa yang terjadi di lapangan. Pasalnya, berdasarkan pengalaman di Banyuwangi, pengenalan teknologi dan IT dapat menjadi jalan pembuka bagi reformasi tatakelola pemerintahan yang lebih jauh.

West (2004: 15), menyetujui Fountain (1999) \& Quinn (1992), bahwa perubahan di pemerintahan hanya mungkin terjadi secara inkremental. Yang dimaksud dengan perubahan yang inkremental adalah perubahan yang dilakukan secara setahap demi setahap. Dengan pengertian ini seolah-olah West ingin menyebut bahwa semua perubahan yang berbasis IT itu coraknya revolusioner. Artikel ini mempertanyakan pandangan tersebut untuk beberapa alasan. Pertama, ukuran sesuatu disebut inkremental itu tidak jelas. Tidak ada kesepakatan di antara para ilmuan terkait dimensi waktu dalam memahami sebuah perubahan itu disebut inkremental atau revolusioner, berapa angka tahun yang secara pasti dapat digunakan untuk menyebut sebuah periode itu inkremental, apakah 5 tahun atau sepuluh tahun atau 20 tahun. Kedua, adopsi teknologi dalam pemerintahan tidak selalu berarti ekuivalen dengan perubahan revolusioner. Organisasi pemerintahan berbeda dengan organisasi swasta dan masyarakat sipil. Tatakelolanya diikat oleh birokrasi yang panjang baik dalam perencanaan maupun penganggarannya. Menyebut pengenalan IT sebagai sesuatu yang revolusioner jelas adalah sesuatu yang sulit diterima.

Oleh karena itu, mendiskusikan IT dalam inovasi tatakelola pemerintahan sebaiknya tidak melulu dilihat dari perspektif waktu (inkrementalis atau revolusioner). Sebaliknya, mendiskusikan IT dalam inovasi tatakelola pemerintahan jauh lebih penting untuk diulik dari sisi apakah IT diletakkan sebagai core (inti) atau sekedar sebagai instrumen, guna memperoleh penjelasan bagaimana IT menginduksi perubahan- 
perubahan lain dalam lembaga pemerintah dan tatakelola pemerintahan secara lebih luas. Di poin inilah paper ini berusaha membangun posisinya.

\section{Membangun Tata Kelola Pemerintahan Berbasis IT}

Banyuwangi sebelum tahun 2010 dikenal sebagai salah satu daerah tertinggal di Jawa Timur, walaupun secara strategis lokasinya menghubungkan Jawa dengan Bali, provinsi yang menjadi tujuan wisata utama di Indonesia. Tingkat kemiskinan Banyuwangi tinggi, bahkan Banyuwangi terkenal dengan sejarah kelam tragedi santet di masa transisi 1990-an. Salah seorang informan mengibaratkan, Banyuwangi sebelumnya seperti orang yang tidak pernah mandi dan berhias/berdandan . Terlebih dengan letak geografisnya di paling ujung timur Pulau Jawa, Banyuwangi hanya menjadi perlintasan orang yang akan berwisata ke Bali. Tanpa terobosan berarti, Banyuwangi tetap menjadi wilayah perlintasan sehingga gagal memanfaatkan peluang menampilkan potensi wilayahnya yang kaya akan ragam sumber daya maupun daya tarik.

Hal inilah yang menjadi salah satu faktor pendorong bagi pemerintah Banyuwangi untuk membuka diri dan mengenalkan potensi Banyuwangi khususnya melalui penggunaan media sosial. Masifnya penggunaan media sosial menuai hasil yang menggembirakan termasuk perolehan penghargaan dari United Nation World Tourism Organization (UNWTO) pada tahun 2015 karena dianggap sukses melakukan rebranding melalui media sosial. Banyuwangi pun dikenal tidak hanya pada tingkat nasional namun telah mendunia. Hal ini berarti kiprah pemerintah daerah dan stakeholder di Banyuwangi setelah tahun 2010 membawa hasil dan dampak yang menggembirakan. Proses perubahan dalam kurun waktu 5 tahun tersebut berhasil mengubah Banyuwangi sebagai sosok yang rajin berhias dan mandi menata diri untuk dipandang secara layak.

Proses perubahan yang terjadi dimulai tahun 2010 saat Abdullah Azwar Anas terpilih menjadi Bupati Banyuwangi masa jabatan 2010-2015. Di luar kelaziman yang selama ini terjadi, Bupati Anas menginginkan formasi Calon Pegawai Negeri Sipil (CPNS) yang akan direkrut memiliki kualifikasi yang cukup tinggi, yaitu 20 sarjana Akuntansi dengan IPK 3,5 serta 10 sarjana Teknologi Informasi dengan Indeks Prestasi Kumulatif (IPK) sama yakni 3,5. Untuk ukuran Kabupaten Banyuwangi hal ini tentu sangat tinggi standarnya. Namun Bupati Anas memiliki argumen yang cukup kuat. S1 Akuntansi direkrut untuk memperbaiki kinerja keuangan karena mengandalkan sumber daya manusia yang telah ada dan tidak semuanya berbasis keuangan makan akan sangat sulit. Adapun Sarjana TI direkrut untuk menata kinerja pemerintah agar menjadi lebih modern, lebih cepat, lebih sederhana, lebih mampu mengantisipasi perkembangan jaman.

Entry point penataan dilakukan melalui tata kelola Sumber Daya Manusia (SDM) karena SDM merupakan kunci strategis dalam pengelolaan segal hal termasuk pemerintahan. Apabila SDM bermasalah maka hal yang lain juga akan bermasalah . 
Oleh karena itu sangat penting memiliki perencanaan yang matang berkaitan dengan SDM agar aspek tata kelola yang lain juga bisa diperbaiki dan membawa manfaat lebih besar.

Proses penggunaan teknologi informasi di Banyuwangi pada awalnya sama dengan pelaksanaan penggunaan pada daerah-daerah lain. Sistem pengadaan barang dan jasa yang melibatkan pihak penyedia jasa atau pihak ketiga menjadi salah satu pilihan yang mudah dan nyaman. Pemerintah daerah hanya menyediakan anggaran dan spesifikasi kebutuhan selanjutnya dilakukan pengadaan barang dan jasa melalui proses pelelangan. Skema ini memang tersedia dalam proses kegiatan pengadaan barang dan jasa yang dilakukan oleh pemerintah maupun pemerintah daerah. Adapun skema kegiatan dan penganggaran mengikuti berjalannya tahun anggaran.

Sepintas hal yang sederhana ini memudahkan dan menguntungkan semua pihak, baik pemerintah maupun pemerintah daerah selaku pengguna jasa maupun pihak penyedia jasa/swasta. Namun dalam pelaksanaannya lebih banyak membawa kerugian bagi pemerintah dan pemerintah daerah. Karena pelaksanaan anggaran berbasis tahun anggaran atau tahunan maka skema pengadaan barang dan jasa berkaitan dengan teknologi informasi juga mengikuti skema ini. Akibatnya banyak pengadaan barang dan jasa di bidang ini yang hanya berumur 1 tahun dan setelah itu tidak bisa dilanjutkan atau diperpanjang lagi. Lebih parahnya sistem teknologi informasi yang telah dibangun, seperti website maupun aplikasi, C-Panel dan password untuk mengedit, mengubah, memutakhirkan, dan melanjutkan sistem yang ada tidak diberikan oleh penyedia jasa kepada operator pemerintah daerah. Hasilnya semua sistem teknologi informasi yang telah terbangun dan digunakan selama 1 tahun menjadi sia-sia .

Pola ini merupakan tipikal kegagalan dalam penggunaan dan pengembangan sistem teknologi informasi pemerintah karena tidak adanya koordinasi dan sinkronisasi antara sistem teknologi infromasi yang dibutuhkan dengan tata kelola anggaran yang dijalankan. Untuk itu menyikapi kegagalan ini tidak ada jalan lain yang ditempuh selain belajar secara otodidak untuk membuat aplikasi maupun sistem teknologi informasi agar dapat digunakan secara berkesinambungan. Sudah tentu untuk menata hal ini diperlukan sumber daya manusia yang berkualitas dan memadai. Untuk itu sangat tepat langkah yang ditempuh oleh Bupati Banyuwangi dengan melakukan rekrutmen sumber daya manusia untuk mengelola sistem teknologi informasi dengan kompetensi yang cukup tinggi standarnya.

Hasilnya sampai dengan tahun 2019 Kabupaten Banyuwangi memiliki 13 orang tenaga teknisi aplikasi, 12 tenaga infrastruktur jaringan serta 2 orang tenaga desain grafis. Hal ini masih didukung oleh tenaga Non-ASN serta 1.000 relawan Pasukan Media Sosial yang direkrut secara sistematis untuk memberikan input/masukan data maupun informasi maupun output/luaran berupa broadcast message baik melalui media sosial personal maupun platform website. Untuk kepentingan ini secara periodik dilakukan pendidikan dan latihan (diklat) maupun bimbingan teknis (bintek) singkat guna 
meningkatkan kemampuan dan ketrampilan serta memperluas jejaring, baik dalam lingkup Organisasi Pemerintah Daerah Kabupaten Banyuwangi sampai dengan kewilayahan (RT, RW, kelurahan, desa, kecamatan).

Pengelolaan ini diikuti dengan proses digitalisasi dan sinkronisasi sistem bisnis internal pemerintah daerah maupun eksternal. Dalam sistem bisnis internal, tata kelola sumber daya manusia berkaitan dengan kehadiran dan kinerja dikelola dengan sistem insentif E-Kinerja sehingga memberikan kemudahan dalam penggunaan, penghitungan, dan pemberian penghasilan tambahan berupa insentif. Tidak ada lagi sistem pemberian insentif yang bersifat sama rata, namun betul-betul dilakukan dengan berbasis kinerja yang terekam dalam sistem teknologi informasi. Secara strategis hal ini merupakan motor penggerak inovasi pemerintah daerah di Banyuwangi. Sumber daya manusia yang paham tentang teknologi informasi menjadi perintis dan penggerak pada setiap sektor yang ada. Khusus pada sektor pemerintah daerah, pengelolaan tata kerja sebagaimana telah disebut di atas memberikan kesan dan bukti yang positif bagi publik karena kinerja yang sistematis, terukur, terdokumentasi, dan memberikan manfaat.

Pada sistem eksternal pemerintah daerah, desain penggunaan teknologi informasi dilakukan sampai ke ranah desa dengan nama Smart Kampung. Selain penyediaan sarana internet gratis di setiap desa dan kelurahan bagi warga untuk kepentingan pembelajaran anak sekolah, bisnis, maupun urusan-urusan yang berhubungan dengan pemerintah, pemerintah daerah juga menyediakan platform untuk informasi dan komunikasi publik melalui https://www.banyuwangikab.go.id/ yang berisi informasiinformasi dinamis (termutakhirkan setiap saat). Bahkan pengelolaan dan penggunaan anggaran oleh Pemerintah Kabupaten Banyuwangi secara real time harian dapat diakses secara terbuka oleh publik. Secara komprehensif, baik hardware maupun software teknologi informasi telah tersedia, tertata, dan digunakan baik oleh pemerintah daerah maupun masyarakat. Sejumlah 189 desa telah menggunakan fiber optik sehingga proses digitalisasi dapat berlangsung sampai ke seluruh pelosok wilayah.

Keberhasilan ini telah membuahkan hasil berupa penghargaan yang diterima oleh Bupati maupun pemerintah daerah. Tercatat sejumlah 165 penghargaan baik tingkat regional Provinsi Jawa Timur, nasional, maupun internasional telah diterima selama kurun waktu tahun 2011 sampai dengan 2020. Penghargaan yang diterima lebih banyak berkaitan dengan tata kelola yang salah satunya berhubungan dengan penggunaan teknologi informasi serta inovasi-inovasi yang telah dilakukan dalam segala aspek kinerja pemerintah daerah. Hal ini membuktikan bahwa penggunaan teknologi informasi yang berkolaborasi dengan tata kelola sumber daya manusia menjadi kombinasi yang tepat mewujudkan inovasi, perbaikan, maupun pencapaian kinerja di segala bidang.

Atas keberhasilan yang telah dicapai ini mengundang banyak daerah untuk datang melakukan studi banding bahkan mengadopsi sistem teknologi informasi yang telah dibuat dan dijalankan oleh Pemerintah Kabupaten Banyuwangi pada semua 
Organisasi Perangkat Daerah (OPD) yang ada. Beberapa daerah seperti Kabupaten Enrekang, Manggarai, Konawe, dan Tapanuli Selatan mengadopsi sistem aplikasi pengelolaan keuangan daerah dari Kabupaten Banyuwangi yang diperoleh secara cumacuma. Syaratnya hanya menugaskan staf operator untuk magang selama 30 hari di Kabupaten Banyuwangi sebagai bentuk transfer of knowledge. Daerah-daerah yang lain juga mengundang narasumber dari OPD terkait pada Pemerintah Kabupaten Banyuwangi untuk memberikan seminar, pelatihan, maupun bimbingan teknis tata kelola berbasis teknologi informasi. Hal ini semakin meneguhkan bahwa praktik tata kelola maupun inovasi berbasis teknologi informasi yang telah dirintis dan dikembangkan oleh Pemerintah Kabupaten Banyuwangi mendapatkan pengakuan baik dari pemerintah, swasta sampai ke tingkat internasional maupun sejawat pemerintah daerah se-Indonesia.

\section{Implikasi Lanjutan Inovasi Berbasis IT pada Berbagai Sektor}

Menariknya dari transformasi Banyuwangi menjadi kabupaten dengan tatakelola pemerintahan berbasis IT adalah dampak ikutannya yang meluas ke ranah-ranah lain. Tidak hanya pada pelaksanaan urusan sehari-hari tatakelola pemerintahan seperti $e^{-}$ planning dan e-budgeting, pelayanan publik seperti pelayanan kependudukan dan kesehatan juga mengalami lompatan perbaikan yang signifikan. Selain itu, dampak ikutan inovasi kebijakan berbasis IT juga menjalar ke sektor ekonomi dan pariwisata, sektor-sektor yang berkaitan erat dengan ranah masyarakat dan dunia usaha.

Di sektor tatakelola pemerintahan sehari-sehari, sejak 2014 Banyuwangi terpilih menjadi kabupaten dengan perencanaan pembangunan terbaik. Di samping itu, Banyuwangi juga terpilih menjadi Kabupaten dengan Tata Ruang terbaik. Tidak hanya dalam perencanaan dan implementasi, Banyuwangi juga berkali-kali menyandang Kabupaten dengan nilai SAKIP (Sistem Akuntabilitas Kinerja Instansi Pemerintah) sempurna (nilai AA), yang mengindikasikan kesesuaian perencanaan, implementasi dan pelaporan kinerja sesuai dengan prinsip-prinsip transparansi dan akuntabilitas, disertai dengan inovasi yang berhasil. Berbagai penghargaan tatakelola pemerintahan yang mencakup perencanaan, pelaksanaan dan pelaporan ini tergambar dengan jelas dalam pelayanan publik sehari-hari.

Di bidang kependudukan dan perijinan, pemerintah Banyuwangi mengefektifkan penggunaan aplikasi online. Untuk kependudukan, SIAK (Sistem Informasi Administrasi Kependudukan) digunakan untuk mengefektifkan pelayanan. Dengan akses internet sampai tingkat desa, masyarakat tidak perlu lagi datang bolak-balik ke kota untuk mengurus semua keperluan administrasi kependudukan. Masyarakat cukup mengisi aplikasi online, lalu menyiapkan syarat-syarat yang diperlukan dan mengirimkannya kembali secara online. Untuk dokumen selain KTP dan KIA, seperti KK (Kartu Keluarga), akta kelahiran, akta kematian dan akta perkawinan khusus non-muslim, setelah semua proses registrasi online, pengiriman syarat-syarat dan verifikasi lengkap, 
dokumen kependudukan dalam bentuk pdf bisa dicetak sendiri. Terkait keabsahan atau legalitas dokumen tersebut, pemerintah telah mencantumkan barcode dan Tanda Tangan Elektronik (TTE). Sementara itu, untuk pelayanan perijinan, pemerintah Banyuwangi menyediakan Mal Pelayanan Publik. Masyarakat cukup mengisi syarat yang diperlukan secara online melalui aplikasi Smart Kampung, lalu datang ke Mal Pelayanan Publik dengan scanning e-KTP dan melanjutkan dengan cetak dokumen yang diperlukan.

Di sektor kesehatan, pelayanan online dimulai dari proses pendaftaran pemeriksaan kesehatan yang bisa dilakukan via aplikasi Whatsapp atau telepon sampai dengan pengambilan obat. Pasien tidak perlu menunggu lama hanya denhan mendapatkan nomor antrian dan jam periksa dinformasikan lewat Whatsapp atau telpon, sehingga pasien cukup datang tepat sesuai jam periksa. Pasien dengan kebutuhan khusus atau memiliki penyakit kronis di rumah sakit diberikan kartu khusus sehingga mereka tidak perlu mengantri baik saat periksa maupun mengambil obat. Jika diperlukan, pengambilan obat tidak perlu mengantri dan cukup dilakukan lewat ojek online. Bagi keluarga yang baru saja melahirkan, pemerintah menerapkan kebijakan pelayanan threein-one "Lahir Procot Pulang Langsung Bawa Akte", dimana keluarga tersebut akan otomatis mendapatkan Kartu Keluarga Baru, Akta Kelahiran dan Kartu Identitas Anak dalam 1-2 hari dengan catatan semua persyaratan lengkap. Ini belum menyebut berbagai terobosan lain, seperti pasien dengan penyakit menahun, dimana apoteker melakukan pelayanan pengantarasan obat, maupun pengantaran melalui ojek online yang biayanya ditanggung oleh pemerintah.

Di sektor ekonomi, yang bergandengan dengan pariwisata, pemanfataan sosial media untuk membangun jejaring UMKM maupun pemasaran bukan hal yang baru lagi bagi pelaku ekonomi mikro dan menengah di Banyuwangi. Ditambah dengan Banyuwangi menetapkan pariwisata sebagai content bagi semua sektor kebijakan, baik pertanian, perikanan, peternakan, kelautan, maupun budaya dimana semua dikemas sebagai event. Dalam setahun, tercatat ratusan festival digelar di masyarakat dan bergilir antar desa. Event ini menerapkan syarat dan prosedur tertentu, sehingga tidak semua yang mendaftar lolos. Adopsi IT digunakan untuk mendukung pemasaran dan informasi yang merambah berbagai kanal sosial media dan kanal-kanal online lainnya. Hasilnya, tingkat kunjungan wisata di Banyuwangi meningkat tajam. Pada tahun 2013 wisatawan domestik berjumlah 1.057.952 orang, sedangkan tahun 2019 berjumlah 5.307.054 orang. Sementara itu, wisatawan mancanegara pada tahun 2013 berjumlah 10.462 orang, dan pada tahun 2019 jumlahnya meningkat menjadi 101.622 .

Inovasi kebijakan berbasis IT di Kabupaten Banyuwangi yang diawali dari penataan SDM dan digitalisasi berbagai urusan pemerintahan, yang kemudian merambat ke ranah pelayanan publik dan pembangunan di berbagai bidang, tidak hanya di wilayah perkotaan tetapi juga sampai pedesaan, menjelaskan kepada kita bahwa IT dapat menjadi pemicu perubahan di berbagai bidang. Sebagaimana pernyataan salah 
satu informan, "Inovasi di Banyuwangi yang diawali dari ranah IT, dan berhasil, ternyata mendorong inovasi-inovasi lain menjadi lebih memungkinkan dilakukan. Satu inovasi yang berhasil membuat kita "ketagihan" untuk melakukan inovasi-inovasi yang lain berikutnya."

Tentu saja, apa yang pemerintah Banyuwangi mampu capai sejauh ini bukan akhir segalanya. Ada masih banyak kritik dan kekurangan yang memerlukan perbaikanperbaikan, misalnya, masih adanya beberapa desa yang belum terjangkau internet, serta berbagai isu sosial yang lain. Pemerintah Banyuwangi sendiri menyadari hal ini. Namun demikian, pengalaman Banyuwangi memberikan gambaran kepada kita bahwa di tengah pandangan pesimisme tatakelola pemerintahan di Indonesia karena lekat dengan kinerja yang lambat, anti perubahan, dan terbelah, perubahan itu ternyata sangat mungkin untuk diupayakan. Dalam kasus Banyuwangi, menjelaskan perubahan itu tanpa mengulik faktor IT menjadi sesuatu yang tidak bunyi.

\section{IT sebagai Enabler: Membangun Cara Pandang Berbeda}

Apa yang kita lihat dari pengalaman Banyuwangi dalam menata kembali tatakelola pemerintahannya melalui IT menjelaskan kepada kita bahwa IT merupakan gerbang yang krusial guna mendorong terobosan yang lebih luas. Ilmuan boleh skeptis terhadap adopsi IT di pemerintahan, utamanya di negara berkembang, dan berargumentasi tentang ketidakcukupan IT dalam mendorong perubahan kinerja pemerintahan. Tetapi, kasus Banyuwangi memperlihatkan sebaliknya. Dalam pandangan Licht \& Moch (1999) IT tidak memiliki hubungan dengan transformasi tatakelola pemerintahan, karena perubahan budaya organisasi lah yang memegang peranan penting didalamnya. Licht \& Moch (1999) lebih melihat IT sebagai instrumen belaka yang bersifat statis.

Artikel ini tidak melihat IT sebagai hal yang statis. Adopsi IT dapat juga mendorong berbagai perubahan sosial. Ketika IT ditempatkan secara tepat, sebagaimana yang diperlihatkan dalam kasus di Banyuwangi, IT dapat mendorong perubahan yang signifikan dalam tatakelola pemerintahan, bahkan menginduksi perubahan-perubahan lain, tidak hanya di ranah-ranah pengadministrasian pemerintahan sebagaimana yang dimotori pemerintah, tetapi juga di ranah lain yang dikelola masyarakat. Dalam hal ini, alih-alih bersifat statis, IT justru dapat mengubah perilaku dan budaya organisasi, sehingga menghasilkan kinerja aparat pemerintah yang lebih baik. Dengan demikian, argumen yang meletakkan IT semata sebagai instrumen yang tidak memiliki peran apapun dalam perubahan sosial patut dipertanyakan.

Tentu saja, artikel ini tidak bermaksud mengagung-agungkan IT secara berlebihan dan melihatnya sebagai faktor tunggal dalam inovasi kebijakan. Sebagaimana dijelaskan sebelumnya, ada terobosan penunjang yang menguatkan pengefektivan penggunaan IT dalam inovasi tatakelola pemerintahan. Tata ulang pengelolaan sumber 
daya manusia, sistem insentif dan disinsentif, serta pendekatan dan komunikasi kebijakan yang strategis yang mendukung inovasi berbasis IT di Banyuwangi berhasil dan memicu perubahan-perubahan di sektor lainnya.

Pengadopsian IT dalam tata ulang pemerintahan, diawali dengan kebijakan yang tepat, yaitu perekrutan sumberdaya IT didalam tubuh pemerintah kabupaten sendiri. Pemerintah Kabupaten Banyuwangi menyadari, sebagai kebutuhan yang sudah tidak dapat dihindari lagi, pemerintah harus menguasai sendiri tatakelola IT, sampai ke detil teknis, guna menghindari ketergantungan pada pihak luar. Belajar dari pengalaman tatakelola IT di kabupaten lain, pengelolaan IT yang diserahkan kepada pihak ketiga, sebagus-bagusnya hasil yang diperoleh sesaat setelah piranti IT dibangun, cenderung tidak terjamin keberlanjutannya. Ketika kontrak habis, transfer pengetahuan cenderung tidak terjadi, sekaligus, sulit untuk dilakukan. Padahal, kebutuhan IT tidak akan berlangsung dalam 3 atau 5 tahun saja, selayaknya durasi kontrak kerjasama dengan pihak ketiga. Merekrut SDM IT dalam tubuh internal pemerintah kabupaten adalah langkah strategis awal yang layak diapresiasi.

Setelah perekrutan SDM IT dalam tubuh pemerintah, penataulangan kebijakan insentif juga diperlukan. Pemerintah menyadari, ide-ide inovatif tidak akan berjalan lancar dalam kebijakan, jika yang menjadi tumpuan tidak melihat benefit dari inovasi tersebut untuk diri mereka sendiri. Menyadari hal ini, pemerintah menyiapkan kebijakan insentif (dan disintentif) guna memastikan bahwa ide berjalan dengan baik. Ketika terobosan yang dioperasionalkan sudah menghasilkan dampak yang positif, kepuasan kerja akan mengikuti setelahnya, dan secara natural langkah-langkah inovatif selanjutnya relatif lebih mudah dikelola.

Kebijakan penopang berikutnya adalah komunikasi politik yang jalan. Bupati Azwar Anas adalah sosok yang tidak pernah absen dalam setiap kegiatan pemerintah. Walaupun tidak melulu hadir secara langsung, Bupati selalu menyempatkan hadir secara daring melalui aplikasi-aplikasi yang tersedia dan berdiskusi secata content dengan berbagai pihak. Smart Kampung yang ditopang dengan penyediaan akses internet sampai desa, memungkinkan Bupati menjangkau daerah paling jauh sekalipun dari pusat kota. Hal ini menguatkan sense of belonging warga terhadap kebijakan pemerintah, karena kepala daerahnya selalu hadir untuk mereka.

Pengalaman ini menjelaskan sekali lagi kepada kita bahwa IT bukan sekedar instrumen statis yang tidak bisa kita fungsikan sebagai pemungkin bagi perubahanperubahan kebijakan dan tatakelola pemerintahan lebih jauh. IT di Banyuwangi telah menjadi enabler bagi terobosan-terobosan kebijakan di bidang lain. Tentu saja, sebagaimana dijelaskan di atas, ia mesti ditopang dengan serangkaian pendekatan lain, seperti perekrutan SDM IT yang tepat, tataulang kebijakan insentif dan disinsentif, serta komunikasi kebijakan yang lancar. Terlepas dari berbagai kritik, bahwa Banyuwangi terlalu ideal, sehingga terobosannya tidak mudah dikembangkan di daerah lain, tetapi 
penggambaran detil bagaimana kebijakan itu didesain dan dijalankan, membuat kita lebih mudah membayangkan bagaimana kebijakan yang sama akan diimplementasikan dalam konteks yang berbeda di kabupaten lain.

\section{Penutup}

Diskusi tentang inovasi IT (Informasi dan Teknologi) dalam tatakelola pemerintahan sejauh ini masih berkutat pada IT sebagai instrumen, alih-alih IT sebagai pendorong perubahan lebih luas di berbagai sektor kebijakan. Hasilnya, banyak penjelasan tentang kegagalan adopsi IT di banyak pemerintah daerah. IT dianggap sebagai beban dengan alasan hambatan sumberdaya manusia, hambatan finansial dan hambatan infrastruktur. Tidak heran, banyak daerah yang angkat tangan guna melakukan terobosan berbasis IT didaerah masing-masing. Tidak jarang, untuk menyederhanakan langkah, banyak pemerintah daerah yang justru kemudian menyerahkan pekerjaan kepada pihak ketiga, guna memperoleh hasil yang cepat, walaupun mahal dari sisi keuangan.

Diskusi lain menyebutkan, IT tidak akan bermakna apa-apa jika perubahan budaya organisasi tidak diperkuat. Pandangan ini menimbulkan pertanyaan baru, karena mengubah budaya organisasi juga sama tidak mudahnya dengan mengubah budaya masyarakat. Ide tentang budaya organisasi jauh lebih abstrak ketimbang ide tentang adopsi IT. Sementara itu, sejauh ini, pendekatan tentang pengubahan budaya organisasi bukan tidak ada. Adopsi ide tentang good government sudah mandarah daging didalam tatakelola pemerintahan di Indonesia dan seperti mantra dimana-mana. Akan tetapi, perubahan yang muncul masih sangat pelan, dan dampaknya juga belum benar-benar terasa.

Pengalaman di Banyuwangi menjelaskan kepada kita bahwa kita perlu melihat IT secara berbeda. IT adalah enabler yang memungkinkan perbaikan tatakelola pemerintahan, sekaligus mendorong perubahan-perubahan lain di berbagai sektor kebijakan. Dalam perbaikan tatakelola pemerintahan, IT menunjang pekerjaan administratif lebih efisien, menjangkau pelayanan publik yang luas, sekaligus lebih dekat, dan menghemat biaya dan waktu yang harus dikeluarkan oleh masyaraka guna mengakes pelayanan yang diperlukan. Tidak hanya itu, penguatan IT di Banyuwangi juga meluas di ranah lain. Paling terasa adalah UMKM, dimana jejaring antar pelaku dan distribusi serta pemasaran makin menguat. Pihak lain yang diuntungkan adalah masyarakat desa yang makin gencar mempromosikan potensi budaya di wilayah masing-masing melalui festival tahunan. Tentu saja, adopsi IT tidak berdiri sendiri. Berbagai pendekatan dan kebijakan perlu dibuat untuk menopang keberhasilan adopsi IT sebagai enabler perubahan daerah, mulai dari tatakelola sumber daya, kebijakan insentif, dan komunikasi kebijakan. 
Tentu saja, bukan berarti pengalaman Banyuwangi adalah gambaran sempurna dari adopsi IT dalam terobosan tatakelola pemerintahan. Banyuwangi masih "sekedar" menempatkan dirinya sebagai "user" dari bisnis internet yang jauh lebih luas cakupannya. Namun, penempatan yang tepat sudah sangat berdampak pada perbaikan di berbagai bidang. Ke depan, riset-riset senada perlu diarahkan pada dampak politik terobosan IT, sehingga kepala daerah di wilayah lain memiliki gambaran lebih jelas, keuntungan yang mungkin dan tidak mungkin didapat jika mengadopsi pendekatan serupa.

\section{Ucapan Terima Kasih}

Ucapan terimakasih penulis sampaikan kepada para informan di Banyuwangi atas keterbukaan waktunya selama penelitian lapangan.

\section{Pendanaan}

Pengerjaan artikel ini mendapat bantuan dari Fakultas Ilmu Sosial dan Ilmu Politik, Undip berupa dukungan dana penelitian dengan skema DIPA 2019.

\section{Daftar Pustaka}

Aji, G. G., \& Dharmawan, A. (2018). E-Government to Improve Public Service in Village Difussion of Smart Kampung Innovation in Banyuwang. In 1st International Conference on Social Sciences (ICSS 2018). Atlantis Press.

Asatryan, Z., Heinemann, F., \& Pitlik, H. (2017). Reforming The Public Administration: The Role of Crisis and the Power of Bureaucracy. European Fournal of Political Economy, $48,128-143$.

Asmara, A. Y., \& Rahayu, A. Y. S. (2019). Sustaining Innovation on Public Health Service by Building Creative Culture in Rural Areas: Case on Program of PemburuBumil-Resti at Banyuwangi Regency-Indonesia. In IOP Conference Series: Earth and Environmental Science (Vol. 328, p. 12034). IOP Publishing.

Asmara, A. Y., \& Rahayu, A. Y. S. (2020). Innovation in Delivering Public Health Service: Practice In Banyuwangi Regency-Indonesia. Asmara, A. Y, 12-21.

Buso, M., Marty, F., \& Tran, P. T. (2017). Public-Private Partnerships From Budget Constraints: Looking For Debt Hiding? International Fournal of Industrial Organization, 51, 56-84.

Cheng, H., \& Wang, B. (2019). Multiplier Effect of Science and Technology Innovation in Regional Economic Development: Based on Panel Data of Coastal Cities. Fournal of Coastal Research, 94(SI), 883-890.

Choi, T., \& Chandler, S. M. (2020). Knowledge Vacuum: An Organizational learning Dynamic of How E-Government Innovations Fail. Government Information Quarterly, $37(1), 101416$.

Edmiston, K. D. (2003). State and Local E-Government: Prospects and Challenges. The American Review of Public Administration, 33(1), 20-45.

Effah, J., \& Nuhu, H. (2017). Institutional Barriers to Digitalization of Government Budgeting in Developing Countries: A Case Study of Ghana. The Electronic Fournal of Information Systems in Developing Countries, 82(1), 1-17. 
Foreman-Peck, J. (2013). Effectiveness and Efficiency of SME Innovation Policy. Small Business Economics, 41(1), 55-70.

Fountain, J. (1999). The Virtual State: Toward a Theory of Federal Bureaucracy in The 21st Century. Democracy. Com, 133-156.

Hall, B., \& Van Reenen, J. (2000). How Effective are Fiscal Incentives for R\&D? A Review of The Evidence. Research Policy, 29(4-5), 449-469.

Jacobs, A. M., \& Weaver, R. K. (2015). When Policies Undo Themselves: SelfUndermining Feedback As A Source of Policy Change. Governance, 28(4), 441-457.

Jones, C. I., \& Williams, J. C. (1998). Measuring The Social Return to R\&D. The Quarterly Journal of Economics, 113(4), 1119-1135.

Kakabadse, A., Kakabadse, N. K., \& Kouzmin, A. (2003). Reinventing the Democratic Governance Project Through Information Technology? A Growing Agenda for Debate. Public Administration Review, 63(1), 44-60.

Licht, G., \& Moch, DLicht, G. \& Moch, D. (1999). Innovation and Information Technology in Services. The Canadian Fournal of Economics/Revue Canadienne d'Economiqu, 363-383.

Licht, G., \& Moch, D. (1999). Innovation and Information Technology in Services. The Canadian Fournal of Economics/Revue Canadienne d'Economique.

Marburger, J. H. (2011). Science, Technology and Innovation in a 21st Century Context. Policy Sciences, 44(3), 209.

Quinn, J. B. (1992). Intelligent Enterprise: A Knowledge and Service Based Paradigm for Industri. Simon and Schuster.

Wahono, P. (2016). Public Service Innovation Through the Application of Smart Kampong Concept in Local Government Banyuwangi. In 2016 International Conference on Public Management. Atlantis Press.

Welch, E. W., \& Feeney, M. K. (2014). Technology in Government: How Organizational Culture Mediates Information and Communication Technology Outcomes. Government Information Quarterly, 31(4), 506-512.

West, D. M. (2004). E-Government and the Transformation of Service Delivery and Citizen Attitudes. Public Administration Review, 64(1), 15-27.

Widodo, N. (2019). Innovation Patterns of Local Government in Handling Community Complaints Based on Information Systems (Comparative study in Kota Surabaya and Kabupaten Banyuwangi). In Annual International Conference of Business and Public Administration (AICoBPA 2018). Atlantis Press.

\section{Tentang Penulis}

Teguh Yuwono adalah dosen Ilmu Pemerintahan Fakultas Ilmu Sosial dan Ilmu Politik, Universitas Diponegoro. Penulis memiliki spesialisasi kajian seputar inovasi kebijakan dan tatakelola pemerintahan.

Laila Kholid Alfirdaus adalah dosen Ilmu Pemerintahan Fakultas Ilmu Sosial dan Ilmu Politik, Universitas Diponegoro. Penulis memiliki area riset seputar analisis kebijakan.

Dzunuwanus Ghulam Manar adalah dosen Ilmu Pemerintahan Fakultas Ilmu Sosial dan Ilmu Politik, Universitas Diponegoro. Penulis memiliki minat pada penelitian inovasi dan tatakelola pemerintahan. 